\title{
Optimization of Student Interest Selection Using Artificial Neural Network and Rete Network
}

\author{
M. Syahrul Munir ${ }^{1}$, Eva Y Puspaningrum ${ }^{2}$, Dimas Eko Wicaksono ${ }^{3}$ \\ Department of Informatics, Faculty of Computer Science \\ Universitas Pembangunan Nasional "Veteran" Jawa Timur \\ Jalan Raya Rungkut Madya, Gunung Anyar Surabaya \\ ${ }^{1}$ M.Syahrulmunir@upnjatim.ac.id, ${ }^{2}$ evapuspaningrum.if@ upnjatim.ac.id, ${ }^{3}$ dimaseko.wica@ gmail.com
}

\begin{abstract}
The need for a prospective student to know the interest of the field of study at the college according to his intelligence becomes one of the complex problems. The selection of the right field of study makes the prospective students more enthusiastic to attend college and graduate on time. Therefore an intellectual intelligence test needs to be tested to prospective students with the aim of helping to plan and make decisions about a choice within a college. Through the test, obtained the level of readiness of prospective students to choose a field of study by the level of intelligence it has and minimizes errors in the selection of majors. This study aims to build an expert system application that provides recommendations in the field of study by the results of intellectual intelligence tests offered. The decision-making process of intelligence is based on the theory of IST (Intelligence Structure Test). This application uses forward chaining method optimized with Rete Network in decision-making based on the results of the intelligence test.
\end{abstract}

Keywords-expert system; intelligence test; field study recommendation; IST (Intelligence Structure Test); forward chaining; rete network.

\section{INTRODUCTION}

Over time, the need for a prospective student to know the field of study in a college that is by his intelligence is increasing. This becomes the basic capital of a student to prepare themselves to face the lecture level. It is essential to choose the right field of study so that a prospective student will be enthusiastic in studying and undergoing lectures that are by his interests and talents.

But often prospective students choose a department or field of study because they are carried away or joined with their friends, do not have a view of the existing fields of study in higher education in accordance with their interests, talents and intelligence, choose a field that is perceived as having a level of prestige or popularity the high without paying attention to the interests, talents and intelligence that are in accordance with the background of the education sector. Due to the uncomfortable situation for a student to undergo his studies, many students stop midway or graduate with a modest ability without being able to develop their potential talents.
In this study, an Expert Recommendation System for Higher Education Field Study Using the Forward Chaining Method was optimized with Rete Network, to help provide recommendations to prospective students in order to know the various fields of study in higher education in accordance with the results of intelligence tests so that prospective students can later enthusiasm in studying and undergoing lectures and can develop talents in the lecture period.

\section{LITERATURE REVIEW}

\section{A. Expert System}

In general, expert systems are systems that attempt to adopt human knowledge to computers designed to model the ability to solve problems like an expert. With this Expert System, ordinary people can solve the problem or just search for quality information that can only be obtained with the help of experts in their fields.

\section{B. Intelligence Structure Test}

According to (Andriani, 2016) the structure produced through this IST test shows that each sub-test measures a certain ability. Intellectual abilities that are explored/provoked through each sub-test are as follows:

- SE (Statzerganzng) / Sub-test completes sentence.

- WA (Wortausuahl) / Sub-test looks for different words.

- AN (Analogien) / Sub-test looking for word relationships.

- GE (Gmeinsamkeiten) / Sub-test seeks words that include two senses

- RA (Rechen Aufgaben) / Sub-test simple count.

- ZR (Zahlen Reihen) / Sub-test number series.

- FA (Form Ausuahl) / Sub-test forms.

- WU (Wurfal Aufgaben) / Sub-test matches the image of the cube.

- ME (Brand Aufgaben) / Sub-test remembering words.

\section{Forward Chaining}

According to (Honggowibowo, 2009) an inference multiplication that connects a problem with the solution is 
called a chain. A chain that is searched or passed or traversed from a problem to get the solution is called forward chaining.

Forward chaining or forwarding rules are tested one by one in certain data sequences. In this method, data is used to determine which rules will be executed, then the rule is executed. The process is repeated until it finds a conclusion.

\section{Rete Network}

According to (Kevin \& Hansun, 2015) Rete Algorithm or commonly called Rete Network is a pattern matching algorithm designed by Charles L. Forgy. This algorithm is very efficient for matching facts with patterns in rules/rules. A ruleset is a knowledge base consisting of one or several rules. These rules are usually in the if-then form (IF-THEN). When these rules are suitable for the rete algorithm, they are called Rete Networks.

According to (Friedman-Hill \& Ernest, 2008), a rete algorithm is an algorithm that uses rule-based systems to compare rules or Left Hand Side (LHS) with facts or Right Hand Side (RHS) to get results based on rules.

\section{METHODOLOGY}

This system generally serves to provide recommendations for lecture study areas to users. The workflow of this expert system is that the user will conduct a series of intelligence tests that refer to the IST (Intelligence Structure Test) first so that the system gets the results of each given sub-test. The classification is then conducted to determine the field of study from the results of the intelligence test using the Forward Chaining method which is optimized with Rete Network.

\section{A. Decision-Making System}

In the design, the expert system combines the facts provided and concludes the knowledge that is in the database (knowledge base) using an inference engine created based on existing rules (rules) and run using an inference engine ( inference engine).

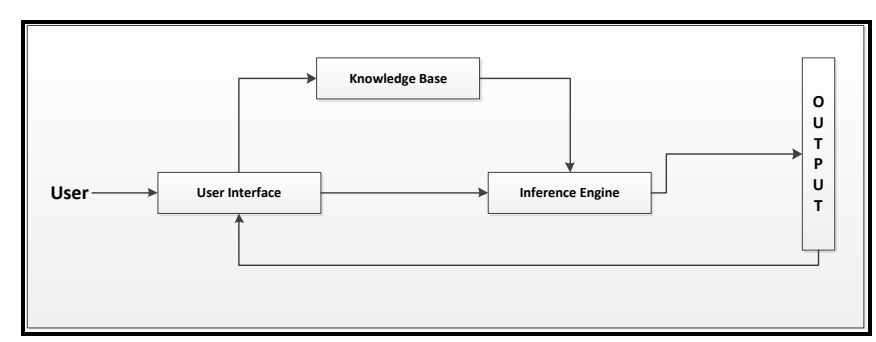

Fig 1. Expert System Architecture Design

In the knowledge base, expert system is needed to know the work order of the application when looking for a decision, in addition to limiting the scope of the problem. The design of the suitability of the field of study according to the IST (Intelligence Structure Test) theory as a knowledge base system is taken from the parameters of the results of the assessment of intelligence tests that were previously entered in the database based on the field of study. Table-I and Table-II are the parameters used in the knowledge base system.
TABLE I. INTELLIGENCE STRUCTURE TEST (SUB-TEST PARAMETER)

\begin{tabular}{|l|l|l|}
\hline Code & Sub Test & Explanation \\
\hline F1 & SE (Satzergazng) & Complete the sentence \\
\hline F2 & WA (Wortausuahl) & Looking for Different Words \\
\hline F3 & AN (Analogien) & Search for word relationships \\
\hline F4 & $\begin{array}{l}\text { GE } \\
\text { (Gmeinsamkeiten) }\end{array}$ & $\begin{array}{l}\text { Look for a word that includes two } \\
\text { senses }\end{array}$ \\
\hline F5 & $\begin{array}{l}\text { RA (Rechen } \\
\text { Aufgaben) }\end{array}$ & Simple count \\
\hline F6 & $\begin{array}{l}\text { ZR (Zahlen } \\
\text { Reihen) }\end{array}$ & Series of numbers \\
\hline F7 & $\begin{array}{l}\text { FA (Form } \\
\text { Ausuahl) }\end{array}$ & Arrange forms \\
\hline F8 & $\begin{array}{l}\text { WU (Wurfal } \\
\text { Aufgaben) }\end{array}$ & Cube \\
\hline F9 & $\begin{array}{l}\text { ME (Merk } \\
\text { Aufgaben) }\end{array}$ & Remembering the Word \\
\hline
\end{tabular}

TABLE II. PARAMETER OF STUDY AREA

\begin{tabular}{|l|l|}
\hline Code & Name of Study Area \\
\hline G1 & Law Studies \\
G2 & $\begin{array}{l}\text { Science of Social Communication and Political } \\
\text { Science }\end{array}$ \\
\hline G3 & Economics \\
\hline G4 & Language and Literature \\
\hline G5 & Psychology \\
\hline G6 & Medical science \\
\hline G7 & Agriculture \\
\hline G8 & Animal Husbandry, Fisheries \\
\hline G9 & Architecture, Visual Communication Design, Art \\
\hline G10 & $\begin{array}{l}\text { Industrial, } \\
\text { Engineering Chemical, }\end{array}$ \\
\hline G11 & Statistics, MIPA \\
\hline
\end{tabular}

Based on Table-I and Table-II in the knowledge base system, the table of relations between the two parameters is arranged as in Table-III below.

TABLE III. RELATIONSHIP BETWEEN THE IST SUBTEST PARAMETERS AND THE STUDY AREA

\begin{tabular}{|l|l|l|l|l|l|l|l|l|l|l|l|l|}
\hline Code & $\begin{array}{l}\text { Sub } \\
\text { Test }\end{array}$ & G1 & G2 & G3 & G4 & G5 & G6 & G7 & G8 & G9 & G10 & G11 \\
\hline F1 & SE & $\sqrt{ }$ & $\sqrt{ }$ & $\sqrt{ }$ & & $\sqrt{ }$ & $\sqrt{ }$ & & & & $\sqrt{ }$ & \\
\hline F2 & WA & & & & $\sqrt{ }$ & $\sqrt{ }$ & & & & & & \\
\hline F3 & AN & $\sqrt{ }$ & $\sqrt{ }$ & $\sqrt{ }$ & $\sqrt{ }$ & $\sqrt{ }$ & $\sqrt{ }$ & $\sqrt{ }$ & $\sqrt{ }$ & $\sqrt{ }$ & $\sqrt{ }$ & $\sqrt{ }$ \\
\hline F4 & GE & $\sqrt{ }$ & $\sqrt{ }$ & & $\sqrt{ }$ & $\sqrt{ }$ & $\sqrt{ }$ & $\sqrt{ }$ & & & $\sqrt{ }$ & $\sqrt{ }$ \\
\hline F5 & RA & & & $\sqrt{ }$ & & & & & & & $\sqrt{ }$ & $\sqrt{ }$ \\
\hline F6 & ZR & & & $\sqrt{ }$ & & & & & & $\sqrt{ }$ & $\sqrt{ }$ & $\sqrt{ }$ \\
\hline F7 & FA & & & & & & $\sqrt{ }$ & $\sqrt{ }$ & $\sqrt{ }$ & $\sqrt{ }$ & $\sqrt{ }$ & $\sqrt{ }$ \\
\hline F8 & WU & & & & & & $\sqrt{ }$ & $\sqrt{ }$ & $\sqrt{ }$ & $\sqrt{ }$ & $\sqrt{ }$ & $\sqrt{ }$ \\
\hline F9 & ME & $\sqrt{ }$ & & & $\sqrt{ }$ & $\sqrt{ }$ & & & & & & \\
\hline
\end{tabular}


After knowing the relationship between each parameter in Table-3, then the following is to make a representation of the knowledge base. The representation used in this research is Rule-Based Knowledge which is the knowledge that is represented in the form of facts (facts). This form of representation consists of a premise (IF) and a conclusion or conclusion (THEN).

TABLE IV.

ULE BASE

\begin{tabular}{|c|c|c|c|}
\hline Rule & IF & Then & Explanation \\
\hline 1 & $\begin{array}{l}\text { F1 \& F3 } \\
\& \text { F4 \& } \\
\text { F9 }\end{array}$ & G1 & Law studies \\
\hline 2 & $\begin{array}{l}\text { F1 \& F3 } \\
\& \text { F4 }\end{array}$ & $\mathrm{G} 2$ & $\begin{array}{l}\text { The science of Social } \\
\text { Communication and } \\
\text { Political Science }\end{array}$ \\
\hline 3 & $\begin{array}{l}\text { F1 \& F3 } \\
\& \text { F5 \& } \\
\text { F6 }\end{array}$ & G3 & Economics \\
\hline 4 & $\begin{array}{l}\text { F2 \& F3 } \\
\text { \& F4 \& } \\
\text { F9 }\end{array}$ & G4 & $\begin{array}{l}\text { Language and } \\
\text { Literature }\end{array}$ \\
\hline 5 & $\begin{array}{l}\text { F1 \& F2 } \\
\& \text { F3 \& } \\
\text { F4 \& F9 }\end{array}$ & G5 & Psychology \\
\hline 6 & $\begin{array}{l}\text { F1 \& F3 } \\
\& \text { F4 \& } \\
\text { F7 \& F8 }\end{array}$ & G6 & Medical science \\
\hline 7 & $\begin{array}{l}\text { F3 \& F4 } \\
\& \text { F7 \& } \\
\text { F8 }\end{array}$ & G7 & Agriculture \\
\hline 8 & $\begin{array}{l}\text { F3 \& F7 } \\
\text { \& F8 }\end{array}$ & G8 & $\begin{array}{l}\text { Animal Husbandry, } \\
\text { Fisheries }\end{array}$ \\
\hline 9 & $\begin{array}{l}\text { F3 \& F6 } \\
\& \text { F7 \& } \\
\text { F8 }\end{array}$ & G9 & $\begin{array}{l}\text { Architecture, Visual } \\
\text { Communication } \\
\text { Design, Art }\end{array}$ \\
\hline 10 & $\begin{array}{l}\text { F1 \& F3 } \\
\& \text { F4 \& } \\
\text { F5 \& F6 } \\
\& \text { F7 } \\
\& \text { F8 }\end{array}$ & G10 & $\begin{array}{l}\text { Industrial, Chemical, } \\
\text { Informatics, Civil } \\
\text { Engineering }\end{array}$ \\
\hline 11 & $\begin{array}{l}\text { F3 \& F4 } \\
\text { \& F5 \& } \\
\text { F6 \& F7 } \\
\text { \& F8 }\end{array}$ & G11 & Statistics, MIPA \\
\hline
\end{tabular}

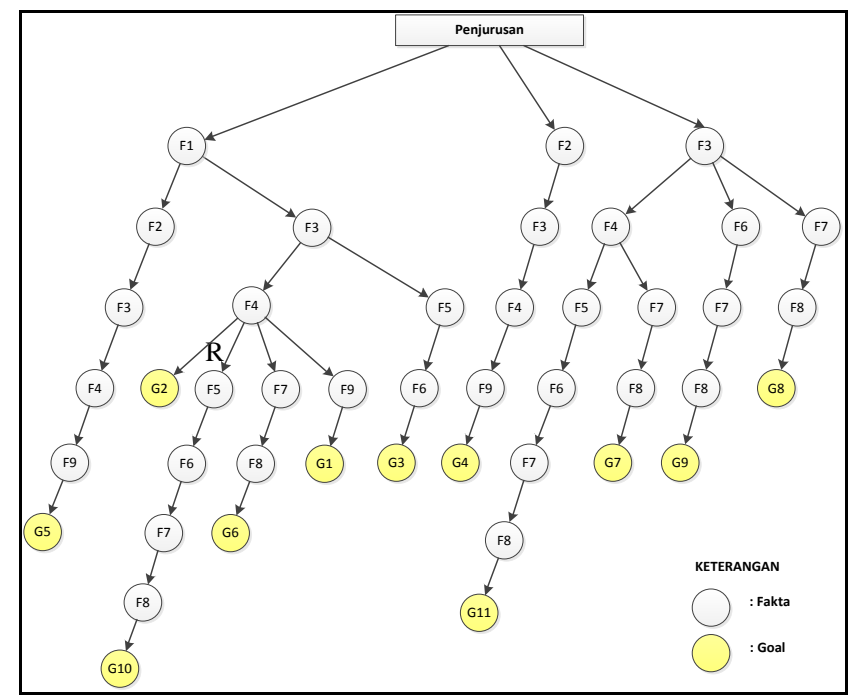

Fig 2. Decision Tree

From Table-IV, the decision tree is designed to help in the reasoning process. The decision tree is a part that acts as an advanced design of the rule base. The concept of a decision tree is to convert data into decision trees and decision rules. The use of decision trees is to break down complex decision making processes to be simpler so that decision-makers will better interpret solutions to problems. Fig 2 is a visualization of the decision tree design.

\section{B. Inference Machine}

Inference machine is a part that acts as a solution seeker of a problem based on the rules that are in the knowledge base in the expert system. In this study, the inference engine was created using the forward chaining method with rete network optimization. Optimization is done in the inference/search process in the decision tree to get efficiency from time and reasoning processes. 


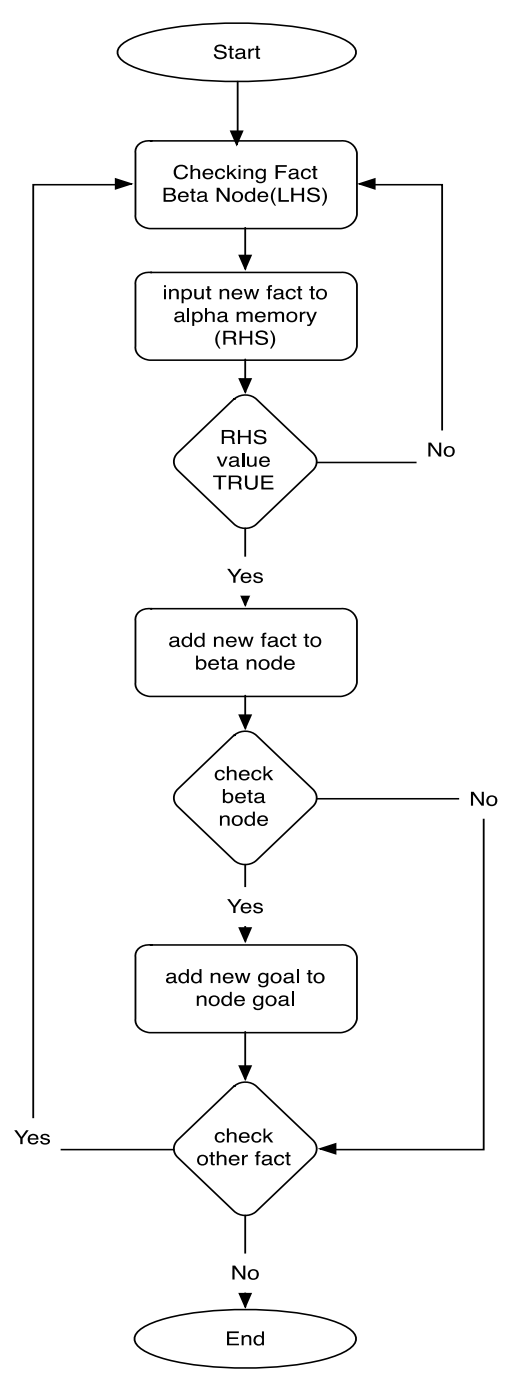

Fig 3. Inference Machine Algorithm

\section{DISCUSSION}

The trial was conducted by high school students and students in East Java province who were willing to assist in the implementation of this research test. The test was conducted to determine the performance of the algorithm implemented in the expert system by comparing the results of the system output and the results of the psychological test recommendations.

These students and students will conduct an intelligence test on the system. Then from the test results will be carried out inference on a database containing various fields of study in universities using inference machines and assisted with the rules given in the classification of study fields according to individual intelligence capabilities. From the above process will produce recommendations in the field of study by the results of intelligence tests that have been conducted. As a comparison of the outputs of our expert systems, we collect data on students who are willing to help, namely in the form of a sheet of recommendations from the field of study that has been carried out when conducting a psychological test at school.
TABLE V. COMPARISON OF RECOMMENDATION RESULT

\begin{tabular}{|c|c|c|c|}
\hline \multirow{2}{*}{ User } & \multicolumn{2}{|c|}{ Recommendation Results } & \multirow{2}{*}{ Similarity } \\
\hline & Psycotest & Expert system & \\
\hline $\begin{array}{l}\text { Riri D. S. } \\
\text { Jatiningtyas }\end{array}$ & $\begin{array}{l}\text { Agriculture, } \\
\text { Animal } \\
\text { Husbandry }\end{array}$ & $\begin{array}{l}\text { Fisheries, } \\
\text { Agriculture, } \\
\text { Animal } \\
\text { Husbandry }\end{array}$ & $\sqrt{ }$ \\
\hline $\begin{array}{l}\text { Reynaldi Zuan } \\
\text { F S }\end{array}$ & Economics & $\begin{array}{l}\text { Economics, } \\
\text { Science of } \\
\text { Medicine, } \\
\text { Economics, Law }\end{array}$ & $\sqrt{ }$ \\
\hline $\begin{array}{l}\text { Lucky } \\
\text { Fernanda S }\end{array}$ & Psychology & $\begin{array}{l}\text { Law Studies, } \\
\text { Social and } \\
\text { Political } \\
\text { Communication } \\
\text { Sciences }\end{array}$ & $x$ \\
\hline Nur Karimah & MIPA, Statistics & $\begin{array}{l}\text { Statistics, MIPA, } \\
\text { Agriculture, } \\
\text { Animal } \\
\text { Husbandry, } \\
\text { Fisheries, } \\
\text { Architecture, } \\
\text { DKV and Arts }\end{array}$ & $\sqrt{ }$ \\
\hline $\begin{array}{l}\text { A Fatur } \\
\text { Rochman }\end{array}$ & $\begin{array}{l}\text { Literature and } \\
\text { Language }\end{array}$ & $\begin{array}{l}\text { Law, Language } \\
\text { and Literature, } \\
\text { Psychology }\end{array}$ & $\sqrt{ }$ \\
\hline $\begin{array}{l}\text { Bryantoro } \\
\text { Prasetyo N }\end{array}$ & $\begin{array}{l}\text { Informatics } \\
\text { Engineering, } \\
\text { Industry, } \\
\text { Chemistry, } \\
\text { Electrical, } \\
\text { Medical } \\
\text { Sciences }\end{array}$ & $\begin{array}{l}\text { Medical } \\
\text { Sciences, } \\
\text { Economics, Law }\end{array}$ & $x$ \\
\hline $\begin{array}{l}\text { Dimas } \\
\text { Fernanda } \\
\text { Bagus D }\end{array}$ & $\begin{array}{l}\text { Economics, } \\
\text { Law Studies, } \\
\text { Statistics, MIPA }\end{array}$ & $\begin{array}{l}\text { Statistics, MIPA, } \\
\text { Agriculture, } \\
\text { Animal } \\
\text { Husbandry, } \\
\text { Fisheries, } \\
\text { Architecture, } \\
\text { DKV and Arts }\end{array}$ & $\sqrt{ }$ \\
\hline Hilda Zulvia & $\begin{array}{l}\text { Psychology, } \\
\text { Literature and } \\
\text { Language } \\
\text { Sciences }\end{array}$ & $\begin{array}{l}\text { Law Studies, } \\
\text { Social and } \\
\text { Political } \\
\text { Communication } \\
\text { Sciences, } \\
\text { Language and } \\
\text { Literature, } \\
\text { Psychology }\end{array}$ & $\sqrt{ }$ \\
\hline
\end{tabular}

\section{CONCLUSION}

After the research process is carried out, it can be obtained some conclusions about the results of the application of the forward chaining method that has been optimized with the rete network in the expert system of high field study recommendations as follows:

1. The Forward Chaining algorithm optimized with Rete Network can be used to determine one's field of study based on the results of the test conducted in the expert system in accordance with the rules that have been set.

2. Based on the results of the testing algorithm, the percentage accuracy results are obtained $81.25 \%$ of the total 16 data available because the expert system cannot handle things that are judgmental (consideration or 
intuition) like a human being. Expert systems provide certain things, so the results released by the system are slightly different from the results given by humans (psychologists). In addition, the factors that exist in the individual when working on the test can also cause the system output to differ from the results of the test.

\section{REFERENCES}

[1] I. Akil, "Effectiveness Analysis of Forward Chaining and Backward Chaining Methods in Expert Systems," Pilar Nusa Mandiri, pp. 35-41, 2017.

[2] R. Amthauer, Intelligenz-Struktur-Test: I-S-T 70. Verlag für: Psychologie Hogrefe, 1973.

[3] N. Andriani, Intelligence Test Guidebook, Padang: Fakultas Psikologi Universitas Putra Indonesia, 2016.

[4] C. Anwar, H. Hermawan, and S. Jaya, Selection System of Study Program Based on Online, Interest, and Intelligence of Students Online Online 8, 2017.
[5] K. Apriyanti and T.W. Widodo, "Optical Character Recognition Based Backpropagation Implementation for Text to Speech Android Devices," IJEIS, Vol. 6 No.1, ISSN: 2088-3714, pp. 13-24, June 2016.

[6] Friedman-Hill and J. Ernest, The Rete Algorithm. 2008.

[7] K. Grzanek, "Transactional Forward Chaining: A Functional Approach," International Conference on Artificial Intelligence and Soft Computing, pp. 613-624, 2015.

[8] A.S. Honggowibowo, Web-Based Plant Disease Diagnosis Exposure System Using Forward and Backward Chaining, 2, 2009.

[9] Kevin and S. Hansun, "Implementation of Rete Algorithm In Expert Systems to Detect Web-Based Autism Spectrum Disorder," Jurnal Ilmu Komputer, 11(1), pp. 55-62, Maret 2015.

[10] I.C. Nugraha and Herlawati, Interest and Talent Test Expert System of Android-Based College Department In Islamic High School Take White Global Bekasi, 2016.

[11] E. Turban, J.E. Aronson, and T.P. Liang, Decision Support System and Intelligent System, 7th ed., Upper Saddle River, NJ: Prentice Hall, 2004.

[12] C. Grannell, The essential guide to CSS and HTML Web Design, New York: Springer-Verlag, 2007. 